\title{
Crimes of Issuing Unbalanced Cheques
}

\author{
Dr Mekhled Ibrahim Al-Zobi \\ School of Law, Police College, Ministry of Interior, Qatar
}

\begin{abstract}
Dealing with cheque has an importance in our entire life as it is used in all fields and domains and is also used a significant source of money. For all of this and for other reasons, the criminal statute had to be taken under consideration to make it legal when dealing with the use of cheques according to Jordanian law and legal contexts. While breaking any of these legal contexts will result into investigation and punishment. According to the law, it is considered a crime to give a cheque with an insufficient balance or giving a cheque that has incomplete or an empty account. The current paper states clearly the following: (1) the consequences of giving a cheque without a balance and (2) explaining how Jordanian law deals with these kinds of crimes.
\end{abstract}

Keywords: Cheque, crimes, Jordanian law, unbalanced cheques, penal code.

DOI: $10.7176 / \mathrm{JLPG} / 104-04$

Publication date: December $31^{\text {st }} 2020$

\section{Introduction}

A cheque has been introduced and is known as a certified document or paper between two parties that the first person orders a bank to pay to the second person a specific amount of money where this process can be done if and only if the following points are available: (1) the given person must have a bank account (2) the person name or the organization the given person is paying to.

Giving cheques with no balance is still considered as a problem that the community is engaged with because of its dangerous consequences [1]. Whereas, the main difference between the cheque and other kinds of commercial formal papers is that it is considered a tool of commitment because it is valid once it is presented to the bank. It is also considered a money receipt that the one who has it can use it whenever he/she likes [2].

The Jordanian constitution establishes the judiciary as one of three separate and independent branches of government. Jordan's present legal system is based on the Constitution, the Court Establishment Law of 1951, a civil and criminal code plus Islamic and ecclesiastical laws in certain cases [3].

\section{Characteristics of cheques comparing to other commercial payment ways}

Cheques are still widely used for many kinds of transactions. For example, this includes paying fesses to a school, utilities to the government, or paying someone for his or her services. There are too many reasons why this tool of payment is still used widely across the world. Despite of its disadvantages it still offers benefits to those who using cheques to make their payments.

The main advantages of using cheques as a method of paying for a certain service are for its safety, its trusted technique, its able to be personalized according to company own customization.

The cheque mainly different from other payment methods that the cheque is a commitment criterion whereas the other methods may be postponed credit. Also, if the cheque is violated, there would be criminal punishment [2].

\section{Cheque crimes}

Cheques are important as much as holding cash money. And for its importance and to keep it as a source of confidence between all beneficiaries, it was subjected to a criminal protection according to Jordanian law where any kind of violations will lead to criminal punishments.

Regarding to Jordanian punishment laws (Penal Code) that was published in 1960 and edited to its last version in 2011, the subject (421) covers the following points for those people who violate using cheques [4]:

1. He shall be punished with imprisonment for a period of no less than a year and not exceeding two years, and a fine no less than one hundred dinars and not exceeding. Two hundred dinars, whoever commits, in bad faith, to commit one of the following acts:

1.1.1. : It does not have an outstanding and exchangeable fulfillment If he issues a check

1.1.2. : If, after issuance of the check, the cash is withdrawn, in exchange for all or part of the check, so that the remainder does not fulfill its value. To the drawee to refrain from cashing the check in cases other than those permitted by law.

1.1.3. : If he issues an order

1.1.4. : If someone shows a check or is payable to his bearer, knowing that he has no compensation that meets his full value or He gave him a check He knows it is not exchangeable

1.1.5. : If he issues a check or signs it in a manner that prevents him from cashing it 
2. Taking into account what is mentioned in section (3) of this article, the court may not, when taking it, with the mitigating reasons in any One of the cases stipulated in Paragraph (1.1.1.) of this Article Reducing the penalty of imprisonment for three months and the fine for fifty dinars. Imprisonment may not be replaced by a fine in these cases

3. Notwithstanding what is stated in section (2) of this Article, the court must rule in the event that the complainant has forfeited his right personal or if the defendant fulfilled the value of the check with a fine equivalent to $5 \%$ of the value of the check provided that it is not less than one hundred dinars even after a judgment is passed or a final degree is acquired.

4. The provisions of section (3) of this Article shall apply to the provisions that have acquired the final degree before the enforcement of the provisions of this the law and the decision to do so in this case is issued by the court that issued the judgment.

\subsection{The crime of the unbalanced cheque}

The crime of an unbalanced cheque is considered a crime when crime here is achieved by the issuing the cheque and the first party knows that there is no cash or enough money in his account to complete the process of money transaction to the second party (the beneficiary) so the drawer shall be responsible for the crime of giving a cheque without balance [2].

\subsection{The punishment of the unbalanced cheque}

Giving a cheque without a balance is considered a felony which is punished by imprisoning for a year and not more than two years and paying a fine no more than two hundred Jordanian Dinars (JOD) and not less than one hundred JOD. On the other hand, the court can use its terms to reduce the imprisoning period for no less than three months and paying a fine not less than 50 JOD.

\section{Elements of the crime of issuing a cheque without balance:}

4.1 The material element (ACTUS REUS) component of the crime

4.2 Pictures of committing of the crime: Upon referring to the text of Article (421) of the Jordanian Penal Code, it has clarified the material components as follow:

4.2.1. If the drawer issued a cheque and has no standing and consumable: If the drawer issues a cheque at a time when there is no fulfillment consideration and that the payment consideration is not exchangeable.

4.2.2. If the drawer, after issuing the cheque, withdraws all or part of the consideration for his payment, so that the balance does not meet its value: The main reason for the punishment for this case is that it includes loosing confidence in the given cheque, because the lawmaker wants the cheque to insure this kind of confidence, starting from the moment it is withdrawn until the moment it is received.

4.2.3. If the drawer issues an order to the drawee to refrain from cashing the cheque in cases other than those permitted by Jordanian law: The drawer has given an order to the drawee bank instructing him not to cash the cheque, whether this order was issued after or before the issuance, so the drawer may not issue an order for that other than in the cases permitted by law.

4.2.4 If the owner of the cheque gives someone a payable cheque and he knows that the it is not cashable or there is no sufficient balance for value of the cheque:

Whoever endorses the cheque knowing that the cheque is not matched with a balance has committed the crime in law of issuing a cheque without balance, and this crime has nothing to do with the drawer's crime.

4.2.5. If he draws a cheque or signs it with his own signiture in a way that prevents it from being cashed:

It is carried out in malignancy on the part of the drawer who approves a change in the document or his signature so that the drawee refuses to exchange the value of the cheque.

\section{The moral element of the cheque crime (MENS REA):}

The crime of issuing a cheque without a balance is an intentional crime. The general criminal intent of knowledge and the criminal intent is achieved as soon as the drawer knows at the time of drawing the check that there is no balance or that it is insufficient to meet the value of the given cheque. It is not required that he has the intention and the well-knowledge of the unavailability of the outcome balance prepared for payment is a presumption In malignancy. This is sufficient for the general criminal intent and the crime of issuing a cheque without a fulfillment balance is a temporary crime.

\section{The Penal Code was recently amended with regard to checks in Jordanian law:}

The cheque must be presented to the drawer's bank within a period of six months from the issuing date of the cheque's, and the punishment in this case is imprisonment for a period of one year. Rather, it is presented in the form of a lawsuit with a claim of personal right to be executed and a demand for the value of the cheque. Usually, the judgment is executed in cases of cheques without balance within a period of one month. 


\section{Conclusion}

The cheque is a method of the commercial papers that can be used for payments procedures between all kinds of benefitants, where this method replaces the cash deals. On such basis, Jordanian laws are initiated to regard the act of giving unbalanced check as a crime punished by law according to the Penal Code.

\section{References}

(1) K Elliott, translated by H Abu Issa and M Al-Atoum, French Criminal Law, Dar Wael First Edition 2020.

(2) B. Malkawi. Contradictory Terms in Cheques: Formalism and Practice. Journal of International Banking Law and Regulation, 2016

(3) K. Ajaj. The Crime of Unbalanced Cheque. IOSR Journal of Humanities and Social Science. 51(1), 2017

(4) Jordan Land Ownership and Agricultural Laws Handbook, Strategic Information and Basic Laws. pp. 26-28, 2011.

(5) jordanian penal code no. 16 of 1960 and his amendment

(6) A Alkhselat, Crimes against Property, Dar Wael First Edition 2020. 